\title{
Field performance of an agricultural tractor fitted with rubber tracks on a low trafficable soil
}

\author{
Giovanni Molari, ${ }^{1}$ Michele Mattetti, ${ }^{1}$ Matthew Walker ${ }^{2}$ \\ ${ }^{1}$ Department of Agricultural and Food Sciences, Bologna University, Bologna; ${ }^{2}$ CNH Italia S.p.a., \\ Modena, Italy
}

\begin{abstract}
The introduction of rubber tracks on tractors has allowed more engine power per unit weight than with steel-tracked tractors, together with a reduction in soil compaction and higher on-road speeds. Recently, triangular rubber tracks able to be adapted on conventional wheeled tractors have been introduced. In this context, the goal of the paper is to evaluate the performance of a tractor with four triangular rubber tracks with respect to those of a wheeled tractor; the comparative tests consist of ploughing under on low trafficable and workable soil. The results obtained have shown a higher tractive efficiency, lower soil compaction and up to $20 \%$ lower specific fuel consumption for the fully tracked tractor. These results are in accordance with previous tests conducted with the triangular rubber tracks on highly trafficable soil, although in the present case, the dynamic traction ratio is markedly lower due to the low trafficable soil. The use of triangular rubber tracks is therefore justified on low trafficable soils and more in general on different soil conditions, since the soil is less compacted by such traction device.
\end{abstract}

\section{Introduction}

In the past 40 years the average farm size has increased in Europe,

Correspondence: Michele Mattetti, Department of Agricultural and Food Sciences, University of Bologna, via G. Fanin 44, 40127 Bologna, Italy.

Tel.: +39.051.2096174 - Fax: +39.051.2096178.

E-mail: michele.mattetti@unibo.it

Key words: Triangular tracks; trafficability; productivity; fuel consumption; cone index.

Acknowledgements: the authors would like to thank L. Bellentani, A. Salamoni, F. Bertelli and the CNH technicians for their help during the tests; R. Canossa, G. Tratta of TIDUE for their technical support.

Received for publication: 31 May 2015.

Accepted for publication: 14 November 2015.

(C) Copyright G. Molari et al., 2015

Licensee PAGEPress, Italy

Journal of Agricultural Engineering 2015; XLVI:477

doi:10.4081/jae.2015.477

This article is distributed under the terms of the Creative Commons Attribution Noncommercial License (by-nc 3.0) which permits any noncommercial use, distribution, and reproduction in any medium, provided the original author(s) and source are credited. so farmers need more powerful machines in order to increase farm productivity and to reduce production cost (Dieter Kutzbach, 2000; Mattetti et al., 2015). For this reason, tractor manufacturers have developed more and more powerful and therefore heavier machines, which exert high loads on the soil and consequently produce high soil stresses. Soil compaction, which is considered to be one of the biggest causes of agricultural soil degradation, determines a crop yield reduction, an increase in soil erosion, and a higher fuel consumption due to the higher tire rolling resistance (Håkansson and Reeder, 1994; Batey, 2009; Chamen et al., 2015).

Soil compaction can be reduced by controlling tires inflation pressure, tractor ballasts weight and using tractors equipped with traction devices with larger footprints, such as tracks. Tracked tractors allow to increase the drawbar pull and to reduce the vehicle slip with respect to wheeled tractors (Zoz and Grisso, 2003; Schjønning et al., 2008). Tractors with steel tracks are falling in disuse and being substituted by tractors with belted rubber tracks, since the latter allow higher on-road mobility and travelling speed (Renius, 1994). In spite of the lower soil compaction, tracked tractors have higher internal resistance with respect to wheeled ones; these may reduce traction efficiency and, consequently, increase the fuel consumption (Bekker, 1956; Turner et al., 1997; Wong, 2001). Recently, triangular rubber tracks, that can be easily mounted on a conventional tractor to increase the drawbar pull, have become available on the market (Ansorge and Godwin, 2007, 2008, 2009; Arvidsson et al., 2011; Molari et al., 2012). These tracks increase the flexibility of conventional tractors because they can be installed in case of low trafficable soils to improve the vehicle floating on the soil. This type of tracks might have lower internal resistance because they are manufactured with a lower number of moving parts than belted tracks.

In this context, the goal of the paper is to evaluate the performance and the fuel efficiency of a tractor with four triangular rubber tracks by comparison with those of a conventional wheeled tractor during ploughing under on low trafficable soils.

\section{Materials and methods}

The tractors used in the tests were the Case Puma 210 fitted with four driving wheels and set with liquid in wheels and front ballast (TA) and the New Holland T7060 fitted with four triangular rubber tracks (TB) (Figure 1). The two models of the same manufacture, dimensions and technical specifications, were fitted with the same engine and full power shift transmission with 19 forward ranges and 6 reverses.

The TB was fitted with front and rear rubber track devices, characterized by a mass of $1300 \mathrm{~kg}$ and $2400 \mathrm{~kg}$ respectively. Each front and rear track produced a theoretical contact area of about $0.890 \mathrm{~m}^{2}$ and $1.713 \mathrm{~m}^{2}$ respectively, instead each front and rear tire produced a theoretical contact area of about $0.116 \mathrm{~m}^{2}$ and $0.158 \mathrm{~m}^{2}$ respectively (Grečenko, 1995). The characteristics of the two tractors are reported in Table 1 and the two tractors have the same load distribution on the 
axles. The tests were performed on a farm in Medesano, Parma, Italy in March 2011. The test field, was not worked for 5 years and was preliminarily worked with a ripper in the previous autumn, to facilitate the soil drainage. The tests were carried on a clay loam soil , according to the United States Department of Agriculture (USDA), soil consistency was evaluated on the basis of the Atterberg's limits (plastic limit $=25 \%$ and liquid limit $=43 \%$ ), the moisture content on dry basis averaged on the first $0.20 \mathrm{~m}$ of soil (between 27 and 31\%) (ASTM, 2010). The soil in which the tests were performed was therefore a low trafficable soil with a consistency index included between 0.66 and 0.89 (Müller et al., 1990). For the ploughing, a mouldboard plough with three bottoms, two ways, semi-mounted hitch was used The mouldboard plough was connected to the tractor through a three-point hitch coupler (ASAE, 2003) on which 3 transducers (HBM, Type U1/10T) were fitted to measure the traction load (Figure 2). To compare the performances of the two different solutions, the ploughing took place at three different depths $(h)$ with the same width $(b)$. For each thesis ( 2 tractors and 3 depths), 20 repetitions with a length equal to $300 \mathrm{~m}$ each, were performed.
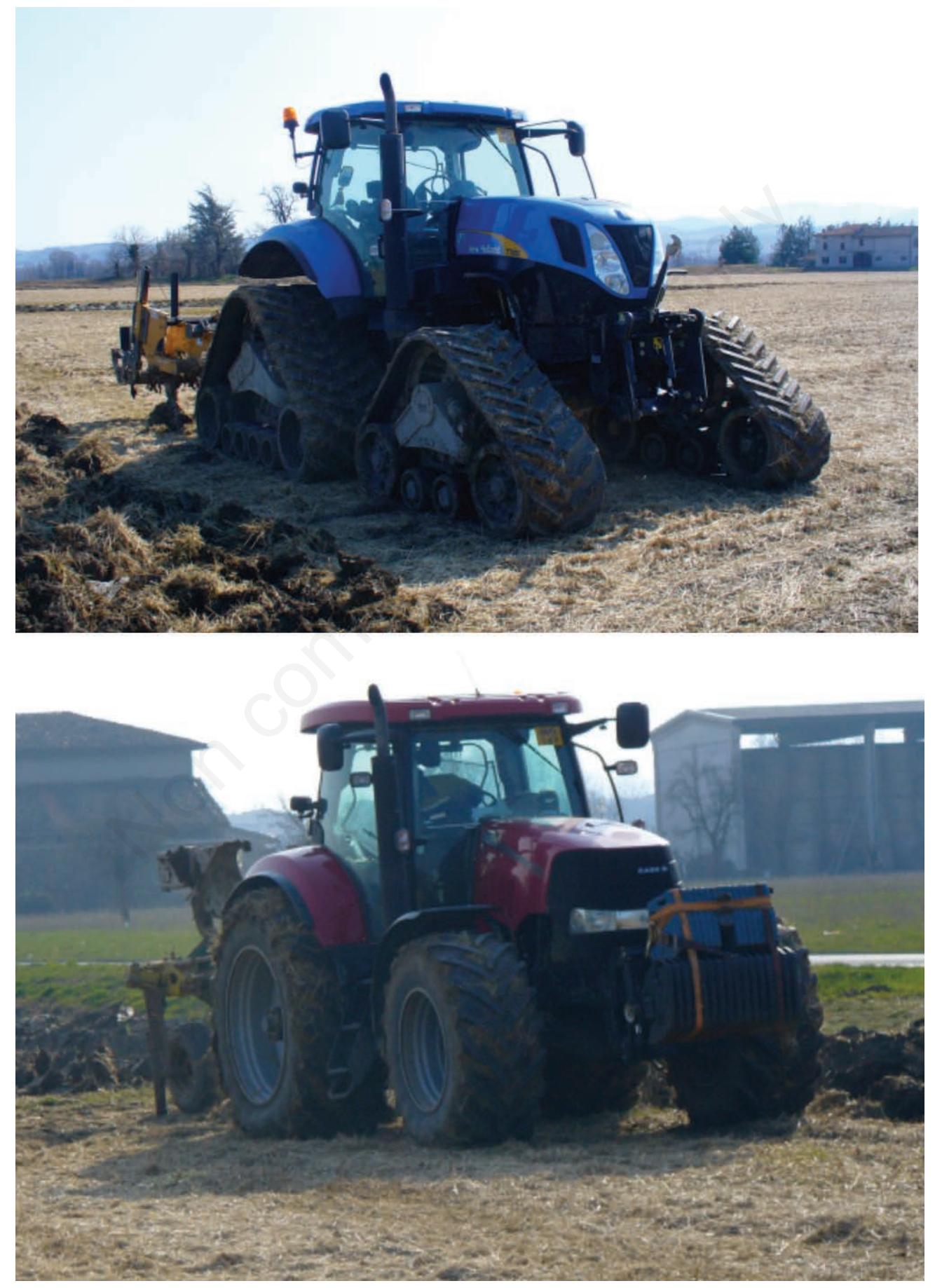

Figure 1. Tractors used in the tests: on the left the tracked tractor, on the right the wheeled tractor. 
The volume of soil worked for each repetition was calculated by measuring the depth and width on the basis of 14 points of measure. The working time for each repetition was measured; the average speed $(v)$ and the hourly volume of soil worked $\left(V_{h}\right)$ were calculated.

The slip $(s)$ was evaluated according to the Organisation for Economic Co-operation and Development (OECD) code 2 (OECD, 2012). The fuel consumption was measured with a volumetric transducer fitted on the fuel input (model fto-3ax; Flow Technology Inc., Tempe, AZ, USA).

These parameters were recorded with an acquisition card (model ecorder; eDaq Inc., Colorado Springs, CO, USA) at a frequency of $50 \mathrm{~Hz}$; the average traction load $(T)$ and the average hourly fuel consumption $\left(Q_{h}\right)$ were calculated for each repetition. Finally, the specific fuel consumption $\left(\mathrm{Q}_{\mathrm{s}}\right)$ and the drawbar power $\left(\mathrm{P}_{\mathrm{g}}\right)$ were calculated:

$$
\begin{array}{ll}
Q_{s}=10^{3} \rho_{\mathrm{f}} Q_{\mathrm{h}} \mathrm{V}_{\mathrm{h}}^{-1} & \left(\mathrm{~g} \mathrm{~m}^{-3}\right) \\
\mathrm{P}_{\mathrm{g}}=10^{-2} \mathrm{~T} \mathrm{v} & (\mathrm{kW})
\end{array}
$$

where fuel density $\mathrm{f}$ was equal to $0.838 \mathrm{~g} \mathrm{~cm}^{-3}$.

The effect of the vehicles transit on soil compaction was evaluated by measuring the bulk density on dry basis and the cone index (CI) values. The bulk density on dry basis was measured in the topsoil with the cylinder method (diameter $0.050 \mathrm{~m}$, height $0.050 \mathrm{~m}$ ). The $\mathrm{CI}$ was calculated on a depth of $0.150 \mathrm{~m}$ with a standard soil cone penetrometer with a head diameter of $0.020 \mathrm{~m}$ (ASAE, 1986, 1999). The dynamic traction ratio $\left(A_{d}\right)$ and the slip efficiency $\left(S_{e}\right)$ were evaluated by:

$$
\begin{array}{ll}
\mathrm{A}_{\mathrm{d}}=\mathrm{T} / \mathrm{m}_{\mathrm{a}} & (\mathrm{kg} / \mathrm{kg}) \\
\mathrm{S}_{\mathrm{e}}=1-\mathrm{s} & \left(\mathrm{ms}^{-1} / \mathrm{ms}^{-1}\right)
\end{array}
$$

where $m_{a}$ is the static load on the driving axles. All the measures were performed in the forward direction of the tractor in correspondence to the marked area before and after the tillage in correspondence of the transit lines not ploughed. The values were calculated on the basis of 20 repetitions for each thesis.

\section{Results and discussion}

The results of the tractive tests on working conditions are reported in Table 2, where, besides the length and depth of the ploughed section, the traction parameters as the slip and the traction load, and the operative parameters as the speed and the fuel consumption, are reported.

In the limited conditions indicated, the higher working depth was acquired with the tracked tractor, equal to $0.48 \mathrm{~m}$, while with the wheeled tractor the maximum depth was equal to $0.44 \mathrm{~m}$. At these depths the traction loads were around $80 \mathrm{kN}$ for the tracked tractor and $66 \mathrm{kN}$ for the wheeled one with a slip for the wheeled tractor twice that of the tracked one. In these conditions the slip efficiency was $84 \%$ for the tracked tractor and $69 \%$ for the wheeled one. For the other two working depths, basically equal for the two configurations, with an equivalent traction load, the slips of the wheeled tractor were three times that of the tracked one.

\begin{tabular}{|c|c|c|c|c|c|c|c|}
\hline Tractor & $\begin{array}{l}\text { Max } \\
\text { power } \\
(\mathrm{kW})\end{array}$ & $\begin{array}{l}\text { Max } \\
\text { torque } \\
(\mathrm{Nm})\end{array}$ & $\begin{array}{l}\text { Total mass } \\
\text { (kg) }\end{array}$ & $\begin{array}{l}\text { Static load } \\
\text { on the front } \\
\text { axle }(\%)\end{array}$ & $\begin{array}{l}\text { Front } \\
\text { track } \\
(\mathrm{mm})\end{array}$ & $\begin{array}{l}\text { Rear } \\
\text { tire }\end{array}$ & $\begin{array}{l}\text { Rear } \\
\text { track } \\
\text { width } \\
(\mathrm{mm})\end{array}$ \\
\hline $\mathrm{TA}$ & 180 & 984 & 14,100 & Goodyear Optitrac DT818 540/65 R30 (16 kPa) & 2334 & Goodyear Optitrac DT818 650/65 R42 (16 kPa) & 2334 \\
\hline TB & 180 & 984 & 14,100 & Tidue Amfibios 24D18 (belt $610 \mathrm{~mm}$ width) & 2984 & Tidue Amfibios 30/36Q23M (belt 915 mm width) & 3015 \\
\hline
\end{tabular}

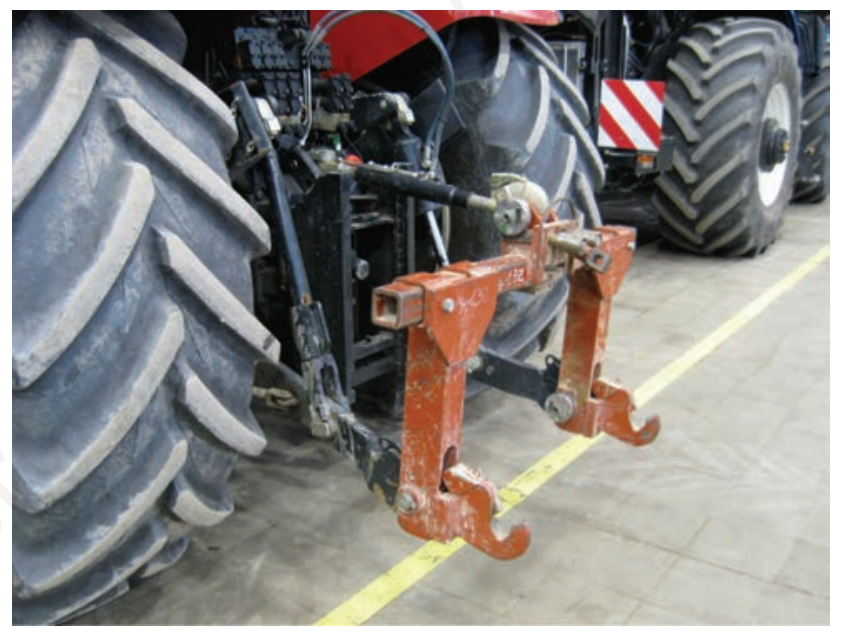

Figure 2. Three-point hitch device coupler.

\begin{tabular}{|c|c|c|c|c|c|c|c|c|c|c|c|c|c|}
\hline \multirow[t]{2}{*}{ Tractor } & & \multicolumn{2}{|c|}{$h$} & \multicolumn{2}{|c|}{$b$} & \multicolumn{2}{|c|}{$v$} & \multicolumn{2}{|c|}{$\mathcal{S}$} & \multicolumn{2}{|c|}{$T$} & \multicolumn{2}{|c|}{ Qh } \\
\hline & & M & St.dev. & $\mathrm{m}$ & St.dev. & $\mathrm{m} \mathrm{s}^{-1}$ & St.dev. & $\%$ & St.dev. & kN & St.dev. & $1 \mathrm{~h}^{-1}$ & St.dev. \\
\hline $\mathrm{TA}$ & hl & 0.39 & 0.02 & 1.35 & 0.01 & 1.52 & 0.05 & 19.8 & 2.1 & 47.26 & 224 & 39.52 & 0.53 \\
\hline TA & h2 & 0.43 & 0.01 & 1.35 & 0.01 & 1.06 & 0.04 & 27.8 & 1.3 & 61.67 & 172 & 39.58 & 0.68 \\
\hline $\mathrm{TA}$ & h3 & 0.44 & 0.02 & 1.35 & 0.01 & 0.95 & 0.05 & 31.2 & 3.1 & 66.13 & 323 & 40.14 & 0.74 \\
\hline TB & hl & 0.38 & 0.02 & 1.35 & 0.01 & 1.84 & 0.05 & 6.2 & 2.2 & 47.45 & 155 & 39.72 & 0.75 \\
\hline TB & h2 & 0.42 & 0.01 & 1.35 & 0.01 & 1.43 & 0.05 & 9.2 & 1.4 & 61.88 & 162 & 39.79 & 0.39 \\
\hline TB & h3 & 0.48 & 0.01 & 1.35 & 0.01 & 1.01 & 0.04 & 16.1 & 1.8 & 80.16 & 220 & 39.21 & 0.61 \\
\hline
\end{tabular}

Table 1. Tested tractor configurations.

Table 2. Working parameters.

St.dev., standard deviation. 
The results in terms of slip and dynamic traction ratio obtained with the tracked tractor on the soil in plastic conditions can be compared with those obtained by Molari et al. (2012) with the same tractor on a highly trafficable soil. With reference to the wheeled tractor, while on the highly trafficable soil (Molari et al., 2012), an increasing of the slip around $5 \%$ was necessary to obtain the same dynamic traction ratio of

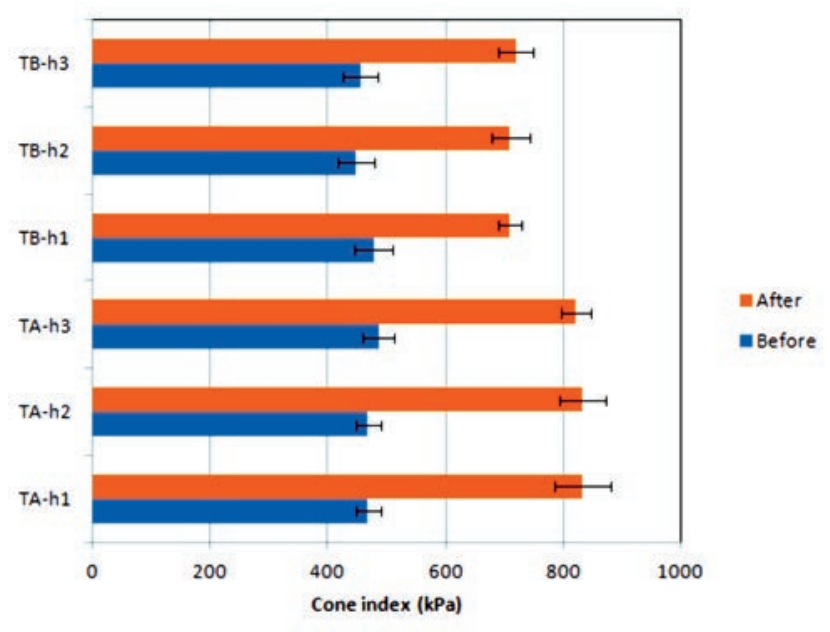

Figure 3. Cone index on dry basis (error bars indicate standard deviation) before and after the passage of the tractor for each test.

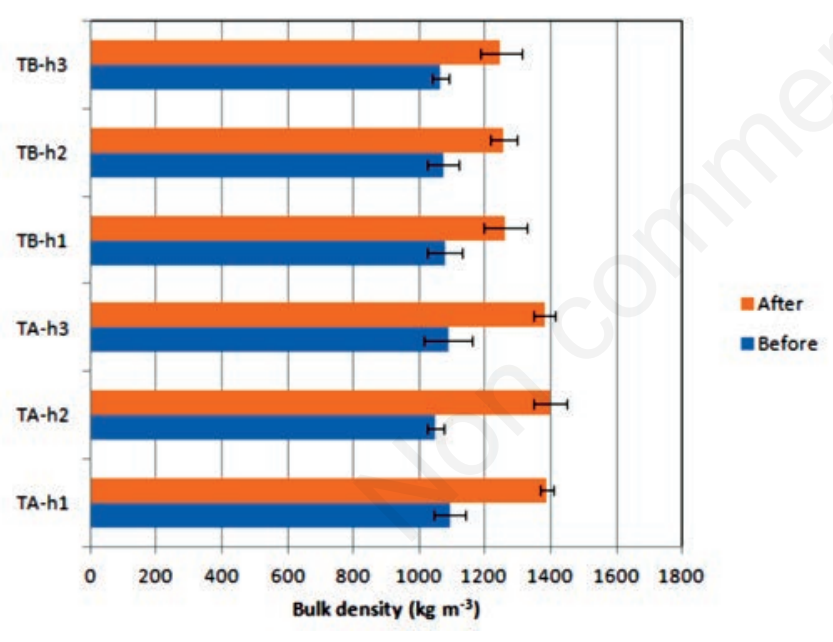

Figure 4. Bulk density on dry basis (error bars indicate standard deviation) before and after the passage of the tractor for each test. the tracked tractor, in the soil of the present study, an increasing of the slip of about $18 \%$ was necessary to achieve the same dynamic traction ratio of the tracked tractor.

With respect to the speed, for the wheeled tractor a relevant reduction from the depth $\mathrm{h} 1$ to the depths $\mathrm{h} 2$ and $\mathrm{h} 3$ with a reduction upper than $30 \%$ was evident, while for the tracked tractor the decreasing speed was more graduated on the three levels with a reduction of $22 \%$ between $\mathrm{h} 1$ and $\mathrm{h} 2$, and of about $29 \%$ between $\mathrm{h} 2$ and $\mathrm{h} 3$. In any case it is evident that the working speeds of the tracked tractor are on average higher than those obtained with the wheeled tractor. The comparison of the traction power in the two configurations show a difference of about $20 \%$ in favour of the tracked tractor (Table 3 ).

The theoretical working capacity measured in terms of hourly volume worked, showed a difference of about $15 \%$ in favour of the tracked tractor in the first depth and of about $25 \%$ on the second one. For the third depth, the difference was around 15\% always in favour of the tracked tractor, despite being obtained with a higher depth. These differences were reproduced in the same way for the specific fuel consumption, with a difference for the tracked tractor up to $20 \%$ in three working conditions.

The analysis of the interaction between the locomotion systems and the soil is strictly connected with the plastic condition of the soil and the moisture content of around $30 \%$. Indeed the consistency status was confirmed by the CI values of the soil before the transit of the tractors, included between 450 and $480 \mathrm{kPa}$ without significant differences in the different thesis (Figure 3).

With reference to the aggregation status of the soil before ploughing, values between 1050 and $1090 \mathrm{~kg} \mathrm{~m}^{-3}$ were recorded without significant differences between the different theses (Figure 4).

As expected and coherently with the results obtained in other experimental conditions (Arvisson et al., 2010; Molari et al., 2012), the soil compaction obtained after the passage of the fully tracked tractor was consistently lower than that obtained with the wheeled tractor. Indeed with reference to the $\mathrm{CI}$ the average value obtained with the tracked tractor was around $710 \mathrm{kPa}$ with respect to $830 \mathrm{kPa}$ for the wheeled one. While the average bulk density was $1250 \mathrm{~kg} \mathrm{~m}^{3}$ for the tracked tractor and $1390 \mathrm{~kg} \mathrm{~m}^{3}$ for the wheeled one.

\section{Conclusions}

The results obtained from the performance comparison between a fully tracked tractor and a wheeled tractor in field tests on a low trafficable soil show a higher performance for the tracked tractor in terms of tractive efficiency, soil compaction and fuel consumption. In these conditions the tracked tractor allows to realise higher traction loads with respect to the wheeled tractor and with the same traction load it shows a slip three times lower. Moreover the tracked tractor realised lower

Table 3. Results obtained in the different configurations tested.

\begin{tabular}{llcccc} 
Tractor & $h$ & $A_{d}$ & $\operatorname{Pg}(\mathrm{kW})$ & Vh $\left(\mathrm{m}^{3} \mathrm{~h}^{-1}\right)$ & $\mathrm{Q}_{s}\left(\mathrm{~g} \mathrm{~m}^{-3}\right)$ \\
TA & $\mathrm{h} 1$ & 0.33 & 71.8 & 2881 & 11.5 \\
TA & $\mathrm{h} 2$ & 0.43 & 65.4 & 2215 & 15.0 \\
\hline TA & $\mathrm{h} 3$ & 0.47 & 62.8 & 2031 & 16.6 \\
TB & $\mathrm{h} 1$ & 0.37 & 87.3 & 3398 & 9.8 \\
\hline TB & $\mathrm{h} 2$ & 0.44 & 88.5 & 2919 & 11.4 \\
TB & $\mathrm{h} 3$ & 0.57 & 81.0 & 2356 & 13.9 \\
\hline
\end{tabular}


fuel consumption up to $20 \%$ than the wheeled tractor.

The tests performed confirm the performances obtained in previous experiences with the tracked tractor on a trafficable soil with a consistent reduction of the dynamic traction ratio that justify the use of these systems on low trafficable soil. The results obtained in these soil conditions show an increasing of the speed and a higher availability of traction power for the tracked tractor with respect to the wheeled one.

In conclusion, the installation of rubber triangular tracks on conventional tractors, especially on low trafficable soils, is a good practice to increase the traction efficiency and to reduce the fuel consumption.

\section{References}

Ansorge D., Godwin R.J. 2007. The effect of tyres and a rubber track at high axle loads on soil compaction, Part 1: Single axle-studies. Biosyst. Eng. 98:115-26.

Ansorge D., Godwin R.J. 2008. The effect of tyres and a rubber track at high axle loads on soil compaction - Part 2: Multi-axle machine studies. Biosyst. Eng. 99:338-47.

Ansorge D., Godwin R.J. 2009. The effect of tyres and a rubber track at high axle loads on soil compaction: part 3: comparison of virgin compression line approaches. Biosyst. Eng. 104:278-87.

Arvidsson J., Westlin H., Keller T., Gilbertsson M. 2011. Rubber track systems for conventional tractors - Effects on soil compaction and traction. Soil Till. Res. 117:103-9.

ASAE. 1986. ASAE S313. 2. Soil cone penetrometer. ASAE, St. Joseph, MI, USA.

ASAE. 1999. ASAE EP 542 Procedures for using and reporting data obtained with the soil cone penetrometer. ASAE, St. Joseph, MI, USA.

ASAE. 2003. ASAE S278.7 - Agricultural wheeled tractors and implements - Three-point hitch couplers - Part 1: U-frame coupler. ASAE, St. Joseph, MI, USA.

ASTM. 2010. D4318 - Test methods for liquid limit, plastic limit, and plasticity index of soils. ASTM International, West Conshohocken, PA, USA.
Batey T. 2009. Soil compaction and soil management - a review. Soil Use Manage. 25:335-45.

Bekker M.G. 1956. Theory of land locomotion: the mechanics of vehicle mobility. University of Michigan Press, Ann Arbor, MI, USA.

Chamen W.C., Moxey A.P., Towers W., Balana B., Hallett P.D. 2015. Mitigating arable soil compaction: a review and analysis of available cost and benefit data. Soil Till. Res. 146, Part A:10-25.

Dieter Kutzbach H. 2000. Trends in power and machinery. J. Agr. Eng. Res. 76:237-47.

Grečenko A. 1995. Tyre footprint area on hard ground computed from catalogue values. J. Terramechanics 32:325-33.

Håkansson I., Reeder R.C. 1994. Subsoil compaction by vehicles with high axle load-extent, persistence and crop response. Soil Till. Res. 29:277-304.

Mattetti M., Molari G., Vertua A. 2015. New methodology for accelerating the four-post testing of tractors using wheel hub displacements. Biosyst. Engine. 129:307-14.

Molari G., Bellentani L., Guarnieri A., Walker M., Sedoni E. 2012. Performance of an agricultural tractor fitted with rubber tracks. Biosyst. Eng. 111:57-63.

Müller L., Tille P., Kretschmer H. 1990. Trafficability and workability of alluvial clay soils in response to drainage status. Soil Till. Res. 16:273-87.

OECD. 2012. CODE 2 - OECD standard code for the official testing of agricultural and forestry tractor performance. OECD, Paris, France.

Renius K.T. 1994. Trends in tractor design with particular reference to Europe. J. Agr. Eng. Res. 57:3-22.

Schjønning P., Lamandé M., Tøgersen F.A., Arvidsson J., Keller T. 2008. Modelling effects of tyre inflation pressure on the stress distribution near the soil-tyre interface. Biosyst. Eng. 99:119-33.

Turner R.J., Shell L.R., Zoz F. 1997. Field performance of rubber belted and MFWD tractors in Southern Alberta soils. SAE J. Automot. Eng. 972730:1-10.

Wong J.Y. 2001. Theory of ground vehicles. John Wiley \& Sons, New York, NY, USA.

Zoz F.M., Grisso R.D. 2003. Traction and tractor performance. ASAE Distinguished Lecture Series n. 27, ASAE, St. Joseph, MI, USA, pp $1-42$. 